\title{
FAKTOR-FAKTOR YANG MEMPENGARUHI KINERJA GURU SMA/SMK KECAMATAN TALEGONG GARUT
}

\author{
Masyono $^{1}$, Didin Saepudin ${ }^{2}$, Taufik Zulfikar ${ }^{3}$ \\ ${ }_{1,2,3}$ Universitas Sangga Buana \\ ${ }^{3}$ korespondensi : taufikzulfikar16@gmail.com
}

\begin{abstract}
Every student's academic success is one of the results of the teacher's performance. Teachers with good performance have the ability to teach students supported by pedagogic competence, social competence, personality competence, and professional competence. Discipline from a teacher is also one of the good and bad factors of a teacher's performance. Teachers with high work commitment will also have high performance as well. This study aims to determine and analyze the effect of competence, discipline, and work commitment on teacher performance in SMA/SMK in Talegong District, Garut Regency. Quantitative methods with descriptive verification approach were used in this study, respondents in this study were 70 high school / vocational high school teachers, survey methods were used to obtain data by distributing questionnaires with 37 closed questions. The analytical tool used is multiple linear regression. The results show that all variables are perceived by the teachers in the very good category. The variables of Competence, Discipline, and Work Commitment have a positive and significant effect on performance either partially or simultaneously.
\end{abstract}

Keywords: Competence, Discipline, Work Commitment,

\begin{abstract}
ABSTRAK
Setiap keberhasilan seorang peserta didik secara akademik merupakan salah satunya hasil dari kinerja guru. Guru dengan kinerja baik memiliki kemampuan dalam mengajar peserta didik didukung oleh kompetensi pedagogic, kompetensi sosial, kompetensi kepribadian, dan kompetensi professional. Kedisiplinan dari seorang guru juga merupakan salah satu faktor baik buruknya kinerja seorang guru. Guru dengan komtmen kerja yang tinggi juga akan memiliki kinerja yang tinggi juga. Penelitian ini bertujuan untuk mengetahui dan menganalisa pengaruh kompetensi, disiplin, dan komitmen kerja terhadap kinerja guru pada SMA/SMK di Kecamatan Talegong Kabupaten Garut. Metode kuantitatif dengan pendekatan deskriptif verifikatif digunakan dalam penelitian ini, responden pada penelitian ini adalah para guru SMA / SMK sebanyak 70 orang, metode survei digunakan untuk memperoleh data dengan menyebarkan kuesioner dengan 37 pertanyaan tertutup. Alat analisa yangdigunakan adalah regresi linear berganda. Hasil menunjukan bahwa semua variabel dipersepsikan oleh para guru pada kategori sangat baik. Variabel Kompetensi, Disiplin, dan Komitmen Kerja mempunyai pengaruh positif dan signifikan terhadap Kinerja baik secara parsial maupun secara simultan.
\end{abstract}

Kata Kunci : Kompetensi, Disiplin, Komitmen Kerja, Kinerja

\section{PENDAHULUAN}

Pendidikan merupakan kunci untuk mengembangkan suatu bangsa [1]. Tanpa pendidikan manusia seakan berada di ruangan tertutup, dan dengan pendidikan seseorang akan menemukan dirinya di sebuah ruangan dengan semua jendela terbuka terhadap dunia luar [2]. Undang-undang Republik Indonesia Nomor 20 Tahun 2003 tentang Sistem Pendidikan Nasional mengatakan bahwa

\section{Pendidikan}

nasional berfungsi mengembangkan kemampuan dan membentuk watak serta peradaban bangsa yang bermartabat dalam rangka mencerdaskan kehidupan bangsa, bertujuan untuk berkembangnya potensi peserta didik agar menjadi manusia yang beriman dan bertakwa kepada Tuhan Yang Maha Esa, berakhlak mulia, sehat, berilmu, cakap, 
kreatif, mandiri, dan menjadi warga negara yang demokratis serta bertanggung jawab.

Tujuan utama pendidikan mengarah kepada pengembangan dan pemberdayaan potensi manusia, sehingga dapat menjadi manusia yang berperadaban, menjaga solidaritas, tulus dalam bekerja kemanusian. Oleh karena itu, pendidikan perlu ditata dengan baik, agar dapat berjalan efektif dan efisien untuk mencapai tujuan (Nata dalam [3]. Indeks Pembangunan Manusia (IPM) mengukur capaian pembangunan manusia berbasis sejumlah komponen dasar kualitas hidup. Sebagai ukuran kualitas hidup, IPM dibangun melalui pendekatan tiga dimensi dasar. Dimensi tersebut mencakup umur panjang dan sehat; pengetahuan, dan kehidupan yang layak. Mengukur dimensi pengetahuan digunakan gabungan indikator angka melek huruf dan rata-rata lama sekolah, rata-rata lama sekolah di Kabupaten Garut masih cukup rendah yaitu hanya sekitar 7,51 artinya bahwa rata-rata penduduk Garut dengan usia di atas 15 tahun hanya mengenyam pendidikan dalam hidupnya selama 7,51 tahun [4]. Berdasarkan data dari BPS tersebut dapat disimpulkan bahwa rata-rata penduduk Garut tidak mengenyam pendidikan sampai tingkat menengah atas. pelaksanaan pendidikan guru merupakan pemegang kunci pengembangan suatu bangsa [1]. Guru merupakan penentu keberhasilan atau kegagalan suatu bangsa [1] dan dianggap sebagai agen yang paling kuat dari perubahan sosial [2]. Kualitas pendidikan, terutama ditentukan oleh proses belajar mengajar tersebut guru memegang peran yang penting. harus diakui bahwa guru adalah kreator proses belajar mengajar. Ia adalah orang yang akan mengembangkan suasana bebas bagi peserta didik untuk mengkaji apa yang menarik dan mampu mengekspresikan ide-ide dan kretivitasnya dalam batas-batas norma-norma yang ditegakkan secara konsisten [3]. Salah satu aspek yang menarik untuk dikaji dari sosok seorang guru adalah aspek kinerja, karena kinerja guru merupakan input yang paling penting dalam penyelenggaraan pendidikan.

Peningkatan kualitas guru sangat penting dalam domain pendidikan, kualitas guru harus didahulukan prioritas lainnya, karena kualitas guru memiliki dampak yang signifikan dan langsung pada siswa penerimaan materi pengetahuan diajarkan (Ugbe \& Agim, dalam [5]. Kualitas seorang guru dapat tercermin dari kompetensi mereka. Guru profesional harus punya kompetensi dan komitmen yang tinggi dalam hal melaksanakan tugas guru (Uno, dalam [6]. Kompetensi pengajaran meliputi perolehan dan demonstrasi keterampilan gabungan yang diperlukan untuk pengajaran siswa seperti memperkenalkan pelajaran, kefasihan dalam bertanya, pertanyaan menyelidik, menjelaskan, kecepatan pelajaran, penguatan, pemahaman psikologi anak, pengenalan perilaku, pengelolaan kelas, dan pemberian tugas. Pengembangan kompetensi harus merupakan proses yang berkelanjutan dalam organisasi [2]. Kompetensi merupakan karakteristik yang mendasari individu yang secara kausal terkait dengan kriteria yang direferensikan untuk hasil kinerja yang efektif dan / atau unggul dalam suatu pekerjaan atau 
situasi. Karakteristik yang mendasari berarti kompetensi adalah bagian yang cukup dalam dan abadi dari kepribadian seseorang serta dapat memprediksi perilaku dalam berbagai macam situasi dan tugas [7]. Kompetensi guru yang diamanatkan oleh Undang-undang Nomor 14 tentang Guru dan Dosen pasal 10 ayat 1, guru harus memiliki kompetensi padagogik, kompetensi kepribadian, kompetensi sosial, dan kompetensi professional.

Disiplin guru adalah salah satu dari beberapa masalah kedisiplinan yang kompleks di sekolah. Disamping disiplin di sekolah juga mencakup disiplin siswa, disiplin kelas, dan sekolah disiplin. Semua disiplin ini adalah pilar utama budaya sekolah [8]. Pentingnya disiplin dan manajemen kelas telah diapresiasi baik dari segi sosial perspektif praktik dan pendirian pengajaran yang efektif [9]. Disiplin merupakan elemen penting untuk kesuksesan siswa secara akademik baik di dalam lingkungan sekolah maupun di luar lingkungan sekolah [10]. Komitmen kerja guru juga menjadi faktor lain yang mempengaruhi kinerja profesional guru. Kurangnya komitmen profesional guru dalam melaksanakan tugas, seperti datang terlambat ke sekolah, sikap acuh tak acuh kepada siswa mengakibatkan kualitas siswa yang buruk [6]. Mengajar bukan hanya pekerjaan yang bertujuan menghasilkan uang untuk mata pencaharian tetapi juga merupakan layanan sosial untuk pembangunan nasional. Seorang guru harus berkomitmen secara permanen pada pekerjaannya [2]. Fakta bahwa komitmen afektif lebih mungkin terjadi menjadi indikator bagaimana guru ingin tetap bersekolah karena mereka ingin, mereka puas dengan sekolah, mereka mengidentifikasi dengan sekolah, dan mereka berjuang untuk sekolah keberhasilan [11]

\section{TINJAUAN PUSTAKA}

\section{Kompetensi}

Kompetensi adalah kemampuan dan karakteristik yang meliputi pengetahuan, keterampilan, dan sikap itu mendasari seseorang dalam usahanya untuk mencapai kinerja yang baik dalam pekerjaannya [12]. Menurut Muhammad Busro dalam [13] Kompetensi adalah segala sesuatu yang dimiliki seseorang baik dari segi pengetahuan, keterampilan, maupun faktor internal lain yang dimiliki oleh seseorang untuk dapat melakukan suatu pekerjaan berdasarkan pengetahuan dan keterampilan yang dimilikinya. Jadi, kompetensi menunjukkan ketrampilan atau pengetahuan yang dirincikan profesionalisme dalam bidang tertentu sebagai sesuatu yang paling penting, sebagai unggulan dalam bidang tersebut. Kompetensi guru merupakan kemampuan seorang guru dalam melaksanakan kewajiban-kewajiban secara bertanggungjawab dan layak menurut Usman dalam [14]. Kompetensi guru menurut Undang-undang Republik Indonesia Nomor 14 Tahun 2005 tentang Guru dan Dosen adalah merupakan kemampuan yang harus dimiliki seorang guru dan dosen berupa kompetensi pedagogic, kompetensi sosial, kompetensi professional, dan kompetensi kepribadian yang bersifat holistic dan merupakan satu kesatuan yang menjadi ciri 
guru professional. Berdasarkan uraian para ahli tersebut maka kompetensi dapat disimpulkan sebagai suatu kemampuan yang harus dimiliki oleh seseorang untuk dapat menyelesaikan suatu pekerjaan. Michael Zwell dalam [13] memberikan lima kategori kompetensi yang terdiri dari: a. Pencapaian tugas merupakan kategori kompetensi yang berkaitan dengan kinerja yang baik. b. Relasi adalah kategori kompetensi yang berhubungan dengan komunikasi dan bekerja dengan baik dengan orang lain serta memenuhi kebutuhannya. c. Atribut pribadi adalah kompetensi intrinsik individu dan menghubungkan cara berpikir orang, rasakan, pelajari dan kembangkan. d. Manajerial adalah kompetensi yang secara khusus berkaitan dengan pengelolaan, pembinaan, dan pengembangan orang-orang. e. Kepemimpinan adalah kompetensi yang berkaitan dengan memimpin organisasi dan orang-orang untuk mencapai tujuan tujuan, visi, dan sasaran organisasi. Menurut Golemen dalam [15] ada 5 karakteristik dari kompetensi yaitu skills (kemampuan), knowledge (pengetahuan), self concepts (attitude, value, self image), traits dan motives (sikap dan motif). Tingginya kompetensi yang dimiliki oleh pegawai akan mewujudkan kinerja yang unggul, karena kompetensi berperan sebagai input, produksi dan proses dalam suatu pekerjaan. Sebagai input, kompetensi adalah kapasitas atau potensi yang muncul dalam diri seseorang untuk menyelesaikan suatu masalah dengan baik. Kapasitas disini terdiri dari pengetahuan, keterampilan dan perilaku. Input kompetensi dapat menggunakan dua bentuk, yaitu kemampuan yang diperoleh dari belajar, latihan atau pengalaman, dan kemampuan yang diperoleh dalam diri individu yang mempengaruhinya dengan kuat. Sementara itu, kompetensi sebagai proses adalah merangkai input dan produksi. Inputnya adalah pengetahuan dan keterampilan, sedangkan produksinya adalah pencapaian hasil yang diinginkan dan proses penggunaan pengetahuan serta keterampilan untuk mencapai tujuan yang dimaksud. Kompetensi guru dapat diukur melalui indikator sebagai berikut [14] : a. Pengelolaan pembelajaran, berkaitan dengan kemampuan guru dalam mengurutkan tujuan pembelajaran secara sistematis, penyesuaian media pembelajaran dengan materi yang disampaikan, penyesuaian pemanfaatan Teknologi Informasi dan Komunikasi sebagai sumber belajar, dan kemampuan guru untuk mengaktualisasikan berbagai potensi yang dimiliki siswa. b. Penguasaan keilmuan, berkaitan dengan keilmuan guru dalam penyesuaian materi pelajaran dengan kompetensi inti dan kompetensi dasar, penggunaan teknik mengelola proses belajar mengajar di kelas, dan penguasaan landasan dan wawasan kependidikan dan keguruan. c. Sikap atau kepribadian, berkaitan dengan kepribadian guru dengan menampilkan diri sebagai pribadi yang jujur, berakhlak mulia, dan teladan bagi peserta didik dan masyarakat, menunjukan etos kerja, tanggungjawab yang tinggi, rasa bangga menjadi guru dan rasa percaya diri, dan menjunjung tinggi kode etik profesi guru. d. Interaksi sosial, berkaitan 
dengan interaksi guru dengan siswa baik selama di sekolah maupun di luar sekolah, berinteraksi dengan sesama rekan kerja, berinteraksi dengan orang tua/wali siswa, dan berinteraksi dengan masyarakat lingkungan sekitar. Dimensi kompetensi berdasarkan Undan-undang Republik Indonesia Nomor 14 Tahun 2005 tentang Guru dan Dosen adalah sebagai berikut : a. Komtensi pedagogic : kemampuan mengelola pemebelajaran peserta didik meliputi pemahaman terhadap peserta didik,perancangan dan pelaksanaan pembelajaran, evaluasi belajar, dan pengembangan peserta didik untuk mengaktualisasi ragam potensi yang dimilikinya. b. Kompetensi kepribadian : mencerminkan kepribadian positif seorang guru yaitu: supel, sabar, disiplin, jujur, rendah hati, berwibawa, santun, empati, ikhlas, berakhlak mulia, bertindak sesuai norma sosial \& hukum. c. Kompetensi sosial : kemampuan guru sebagai bagian dari masyarakat untuk berkomunikasi dan bergaul secara efektif dengan peserta didik, sesama pendidik, tenaga kependidikan, orang tua atau wali peserta didik, dan kemampuan untuk mempergunakan tehnologi komunikasi secara fungsional. d. Kompetensi profesional : kemampuan guru dalam meguasai pembelajaran menncakup: merencanakan, melaksanakan, dan mengevaluasi pembelajaran yang sesuai dengan bidang keahliannya.

\section{Disiplin Kerja}

Hasibuan dalam [16] mendefinisikan kedisiplinan adalah kesadaran dan kesediaan seseorang untuk mentaati semua peraturan organisasi/perusahaan dan norma-norma sosial yang berlaku. Pacitti dalam [17] mengemukakan bahwa disiplin merupakan sikap-perilaku, dan bertindak sesuai dengan aturan perusahaan, baik tertulis maupun tidak. Disiplin juga merupakan kesadaran dan kemauan seseorang untuk menaati semua hukum dan norma sosial yang berlaku. Disiplin karyawan dapat dilihat dari tanggung jawab, sikap, perilaku, dan tindakan seorang seorang karyawan yang mematuhi semua bentuk peraturan selama mereka bekerja. Untuk meningkatkan kinerja, setiap karyawan harus memiliki disiplin kerja dalam organisasi. Indikator dari disiplin kerja : Efektivitas, Ketepatan Waktu, dan Sikap. Disiplin Adalah sebagai sikap mental yang tercermin dalam perbuatan atau tingkah laku perorangan, kelompok atau masyarakat berupa ketaatan (obedience) terhadap peraturan-peraturan atau ketentuan yang ditetapkan pemerintah atau etik, norma dan kaidah yang berlaku dalam masyrakat untuk untuk tujuan tertentu [18]. Anoraga dalam [19] disiplin adalah latihan batin dan watak dengan maksud supaya perbuatannya selalu mentaati tata tertib dan ketaatan pada aturan tata tertib. Berdasarkan uraian para ahli di atas maka disiplin kerja dapat disimpulkan sebagai sikap mental seseorang dimana seseorang harus taat dan patuh terhadap aturan yang berlaku disuatu organisasi agar dapat mencapai tujuan organisasi. Dimensi dari disiplin kerja menurut Siagian dalam [20] adalah disiplin wakru, inisiatif dan kreatif, tanggung jawab, taat pada aturan, sikap dan 
perilaku, teladan kepemimpianan, balas jasa, dan pengawasan melekat. Menurut Siagian dalam [16] menerangkan bahwa dalam penilaian kedisiplinan meliputi : a. Disiplin terhadap kedatangan, b. Disiplin terhadap waktu pulang, c. Disiplin dalam menyelesaikan pekerjaan, d. Disiplin dalam menjalankan peraturan di tempat kerja, e. Disiplin terhadap perintah atasan, f. Disiplin terhadap peningkatan kerja sama.

\section{Komitmen Kerja}

Menurut Carmeli \& Freund; Dan Metiboba, dalam [21] Komitmen kerja merupakan keadaan psikologis yang mencirikan hubungan pekerja dengan pekerjaan.

Sedangkan menurut Bratton dan Gold dalam [21] menyatakan bahwa komitmen kerja adalah rasa komitmen individu untuk bekerja. Kurniadi et al dalam [6] menjelaskan bahwa komitmen guru merupakan tafsir internal seorang guru tentang bagaimana mereka menyerap dan menafsirkan pengalaman kerja mereka. Robbins dan Judge dalam [22] mendefinisikan komitmen kerja sebagai suatu keadaan dimana seorang individu memihak organisasi serta tujuan-tujuan dan keinginannya untuk mempertahankan keanggotaannya dalam organisasi. Komitmen kerja berupa kemauan seseorang untuk mengikat diri serta mampu memberikan bukti loyalitas pada organisasi karena merasa dirinya terlibat dalam kegiatan organisasi tersebut (Wibowo, dalam [23]. Individu tersebut akan menunjukkan keinginan yang kuat untuk menjadi anggota dalam suatu kelompok, kemauan usaha yang tinggi untuk organisasi, dan suatu keyakinan tertentu dan penerimaan terhadap nilai-nilai dan tujuantujuan organisasi (Sutrisno, dalam [23]. Komitmen meliputi tiga aspek yaitu: a. Komitmen afektif, adalah komitmen yang dilandasi oleh rasa keinginan yang tumbuh dari: identitas kepribadian, kepercayaan, hubungan baik dan keterlibatan personal; $b$. Komitmen kontinum, yaitu komitmen yang dilandasi preferensi adanya investasi, ketergantungan, dan pengorbanan secara sosial maupun secara ekonomi; c. Komitmen normatif, adalah komitmen yang dilandasi internalisasi norma dan konstruk psikologis organisasi sehingga tumbuh rasa berbagi tanggung jawab [24].

\section{Kinerja}

Kinerja adalah perilaku, insidental, terukur, dan multi-segi yang ditampilkan setiap Individu sebagai prestasi yang dihasilkan dalam ruang lingkup tanggung jawabnya [12]. Kinerja adalah hasil dari pekerjaan seseorang dalam sebuah organisasi di mana keberhasilannya dapat dinilai melalui ketepatan waktu dari penyelesaian pekerjaan, jumlah pekerjaan yang diselesaikan (kuantitas), dan kualitas hasil pekerjaan [13]. Menurut Wirawan dalam [25] Kinerja adalah fungsi dari kompetensi, sikap, dan tindakan. Kompetensi menjelaskan karakteristik pengetahuan, keterampilan, perilaku, dan pengalaman untuk melakukan pekerjaan atau peran tertentu efektif. Kinerja adalah suatu hasil yang dicapai oleh sesorang dalam melaksanakan tugas atau beban tanggung jawab menurut ukuran dan standar yang 
berlaku pada masing-masing organisasi [18]. Dimensi atau aspek dari kinerja sering diukur secara individu atau kinerja karyawan adalah kinerja tugas, kinerja kontekstual, perilaku kerja yang kontraproduktif, dan kinerja adaptif (Koopmans dalam [12], definisi kinerja tugas sebagai efektifitas yang digunakan oleh pemegang jabatan untuk melaksanakan kegiatan yang berkontribusi pada inti teknis organisasi. Sedangkan kinerja kontekstual berkaitan dengan kontribusi terhadap efektivitas organisasi dengan membentuk sebuah organisasi, sosial, dan konteks psikologis yang berfungsi sebagai katalisator untuk kegiatan dan proses menjalankan tugas. Kinerja Adaptif didefinisikan sebagai tingkatan dimana individu beradaptasi dengan perubahan sistem kerja atau peran kerja (Griffin, Neal, \& Parker, dalam [12]. Contoh nyata kinerja adaptif adalah untuk memecahkan masalah secara kreatif; belajar tugas baru, teknologi dan prosedur; dan mampu beradaptasi dengan individu, budaya, atau lingkungan fisik (Koopmans et al., dalam [12]. Dimensi kinerja menurut Robbins dalam [20] adalah kualitas pekerjaan, kuantitas pekerjaan, ketepatan waktu, efektifitas, dan kemandirian. Kinerja merupakan proses pencapaian hasil, baik secara kuantitas, kualitas pekerjaan /kegiatan / program dengan kemampuan, motivasi, dan peluang dari seorang karyawan (individu), tim, atau organisasi yang ditugaskan tanggung jawab berdasarkan tujuan, sasaran, visi, misi, dan standar. dan waktu yang ditentukan oleh moral dan etika [26]. Kinerja seseorang (termasuk guru) dapat diukur melalui lima indikator berikut: (Uno \& Lamatenggo dalam [14]): a. Kualitas kerja. Indikator ini berkaitan dengan kualitas kerja guru dalam menguasai seagala sesuatu berkaitan dengan persiapan perencanaan program pembelajaran dan penerapan hasil penelitian dalam pembelajaran di kelas. b. Kecepatan/ketetapan kerja. Indikator ini berkaitan dengan ketepatan kerja guru dalam menyesuaikan materi ajar dengan karakteristik yang dimiliki peserta didik dan penyelesaian program pengajaran sesuai dengan kalender akademik. c. Inisiatif dalam kerja. Indikator ini berkaitan dengan inisiatif guru dalam penggunaan model pembelajaran yang variatif sesuai materi pelajaran dan penggunaan berbagai inventaris sekolah dengan bijak. $d$. Kemampuan kerja. Indikator ini berkaitan dengan kemampuan guru dalam memimpin keadaan kelas agar tetap kondusif, pengelolaan kegiatan belajar mengajar, dan penilaian hasil belajar peserta didik.

e. Komunikasi. Indikator ini berkaitan dengan komunikasi yang dilakukan guru dalam proses layanan bimbingan belajar dengan siswa yang kurang mampu mengikuti pembelajaran dan terbuka dalam menerima masukan untuk perbaikan pembelajaran.

\section{Hubungan Kompetensi dengan Kinerja}

Beberapa penelitian yang telah dilakukan dengan tema bahasan hubungan antara kompetensi dengan kinerja adalah sebagai berikut : Penelitian yang dilakukan oleh [26] dengan judul penelitian The Effect Competence And Motivation To Satisfaction And Performance terbit pada jurnal 
International Journal of Scientific \& Technology Research, Vol 8, Issue menunukkan hasil bahwa Kompetensi mempunyai pengaruh positif namun tidak signifikan terhadap kinerja dengan koefisien 0,164 . Penelitian yang dilakukan [21] dengan judul penelitian The dimensions of competency on worker performance mediated by work commitment, Cogent Business \& Management, 7:1 dengan hasil penelitian kompetensi yang terdiri dari pengetahuan, ketrampilan, dan tingkah laku mempunyai pengaruh positif dan signifikan terhadap komitmen pegawai dan kinerja. Penelitian yang dilakukan oleh [27] dengan judul penelitian Competence and Commitment: Two Factors that Impact Performance in Organizations yang terbit pada jurnal Helix, Vol 9, issue 4 pp 5096-5101, hasil penelitian menunjukan bahwa terdapat pengaruh yang positif dan signifikan variabel kompetensi dan komitmen terhadap kinerja pegawai. Penelitian yang dilakukan oleh [25] dengan judul The Effect Work Culture and Competence on Commitement and Employee Performance of PT. Nindya Karya (Persero) terbit pada jurnal Hasanuddin Journal of Business Strategy Vol. 2, No. 1 dengan hasil penelitian bahwa kompetensi mempunyai pengaruh terhadap kinerja pegawai melalui komitmen.

Hipotesis 1 : Terdapat pengaruh kompetensi terhadap Kinerja

\section{Hubungan disiplin dengan kinerja}

Beberapa penelitian yang pernah dilakukan dengan tema hubungan antara disiplin dengan kinerja antara lain yang dilakukan oleh [28] dengan judul penelitian The influence of work training, competence, and discipline of work on employee performance in PT. Lestarindo Perkasa yang terbit pada jurnal Journal of Research in Business, Economics, and Education Vol.1, Issue 2 mengemukakan bahwa jika disiplin kerja ditingkatkan maka kinerja pegawai juga akan meningkat. Penelitian yang dilakukan oleh [16] dengan judul Pengaruh Motivasi, Disiplin Kerja, dan Kompetensi Terhadap Kinerja Pegawai Dinas Pendidikan Kabupaten Sragen yang terbit pada Jurnal Paradigma Vol. 12, No. 01 menemukan bahwa terdapat pengaruh yang positif dan signifikan disiplin kerja terhadap kinerja pada pegawai Dinas Pendidikan Kabupaten Sragen. Penelitian yang dilakukan oleh [17] dengan judul penelitian The Affect of Work Discipline and Competence on Employee Performance (Case Study at Balai Kesehatan Mata Masyarakat Sulawesi Utara) yang terbit pada Jurnal EMBA Vo. 5 No. 3 dengan hasil penelitian menunjukkan bahwa Disiplin Kerja berpengaruh signifikan terhadap Kinerja Pegawai secara partisi. Penelitian yang dilakukan oleh [29] dengan judul Pengaruh Disiplin Kerja, Komitmen Organisasi, dan Kompensasi terhadap Kinerja Pegawai Rumah Sakit Umum Daerah dr. Soekardjo Kota Tasikmalaya yang terbit pada Jurnal Ekonomi Manajemen Vol. 2 Nomor 2, pp 91-104 menemukan fakta bahwa hasil uji statistik disiplin kerja, komitmen organisasi, dan kompensasi berpengaruh positif dan signifikan baik secara bersama-sama maupun parsial terhadap kinerja pegawai Rumah Sakit 
Umum Daerah dr. Soekardjo Kota Tasikmalaya.

Hipotesis 2 : Terdapat pengaruh disiplin kerja terhadap kinerja

\section{Hubungan komitmen kerja dengan kinerja}

Beberapa penelitian yang pernah dilakukan dengan tema hubungan antara komitmen kerja dengan kinerja antara lain yang dilakukan oleh [30] dengan judul The Effect of competence on commitment, performance, and satisfaction with reward as a moderating variable (A study on designing work plans in Kendari City Government Southeast Sulawesi) yang terbit pada jurnal International Journal of Business and Management Invention Vol. 3, Issue 21, pp 18-25 dengan hasil menunjukkan bahwa terdapat pengaruh positif dan signifikan komitmen kerja terhadap kinerja. Penelitian yang dilakukan oleh [23] dengan judul Dampak Komitmen Guru terhadap Kenerja Guru Pada SMP Negeri 1 Panei yang terbit pada Jurnal Manajemen Program Studi Manajemen STIE Sultan Agung Vol. 6 Nomor 1 menunjukan hasil bahwa komitmen guru memiliki pengaruh yang positif dan signifikan terhadap kinerja guru. Penelitian yang dilakukan oleh [24] dengan judul penelitian Pengaruh Kompetensi guru, Komitmen kerja dan Motivasi kerja terhadap Kinerja Guru SMP Andalan di Sleman yang terbit pada Jurnal Penelitian Ilmu Pendidikan Vol. 9, No. 2 dengan hasil penelitian komitmen kerja berpengaruh positif $(\mathrm{b} 2=0,325)$ dan signifikan $(p=0,000)$ terhadap kinerja guru.
Hipotesis 3 : Terdapat pengaruh komitmen kerja terhadap kinerja

Hipotesis 4 : Terdapat pengaruh kompetensi, disiplin kerja, dan komitmen kerja terhadap kinerja

\section{METODE}

Metode kuantitatif digunakan dalam penelitian ini dengan pendekatan deskriptif dan verifikatif. Data diperoleh dengan menyebarkan kuesioner kepada responden sebanyak 70 orang. Responden adalah guru SMA / SMA yang berada di Kecamatan Talegong Garut. Kuesioner terdiri dari 14 indikator kompetensi, 8 indikator disiplin kerja, 6 indikator komitmen kerja dan 9 indikator kinerja guru. Metode penentuan sample yaitu sampling random. Alat analisa yang digunakan regresi linear berganda dengan persamaan sebagai berikut :

$Y_{i}=\alpha+\beta_{1} X_{1}+\beta_{2} X_{2}+\beta_{3} X_{3}$

Dimana :

$\mathrm{Y}=$ Variabel Kinerja Guru

$\mathrm{a}=$ Konstanta

$\mathrm{b}=$ Koefisien regresi

$\mathrm{X} 1$ = Variabel Kompetensi

X2 = Variabel Disiplin Kerja

X3 = Variabel Komitmen Kerja

\section{HASIL DAN PEMBAHASAN}

\section{Data Responden}

Karakteristik responden yang diteliti dikelompokan berdasarkan jenis kelamin, usia, latar belakang pendidikan. 


\section{Tabel 1 : Responden}

\begin{tabular}{llrr}
\hline Keterangan & Kategori & Frekuensi & Persen \\
\hline Jenis Kelamin & Pria & 51 & 73 \\
& Wanita & 19 & 27 \\
\hline Usia & $<25$ tahun & 1 & 1 \\
& $25,1-35$ tahun & 32 & 46 \\
& $35,1-45$ tahun & 30 & 43 \\
& $>45$ tahun & 7 & 10 \\
\hline Pendidikan & Diploma & 0 & 0 \\
& Sarjana & 67 & 96 \\
& Pascasarjana & 3 & 4 \\
\hline Sumber : Data primer yang diolah & &
\end{tabular}

\section{Hasil Uji Validitas dan Uji Reliabilitas}

Variabel Kompetensi, Disiplin Kerja, Komitmen Kerja, dan Kinerja Guru berdasarkan output IBM SPSS 20.0 yang telah direkapitulasi menunjukan bahwa nilai koefisien validitas untuk tiap-tiap variabel menunjukan angka di atas $r$ tabel 0,3 maka pertanyaan-pertanyaan tersebut diputuskan signifikan dan memiliki validitas yang baik. Nilai Cronbach Alpha variabel kompetensi sebesar 0,833. Nilai Cronbach Alpha variabel disiplin kerja sebesar 0,780. Nilai Cronbach Alpha variabel komitmen kerja sebesar 0,719. Nilai Crobach Alpha variabel kinerja guru sebesar 0,812 dimana nilai Crobach Alpha keseluruhan berada di atas 0,6 ini berarti instrument memiliki hasil yang reliabel, sehingga instrument atau angket ini termasuk kepada instrumen reliabel dan konsisten.

\section{Gambaran Persepsi Responden}

Variabel Kompetensi (X1), diwakili oleh 13 (tiga belas) item pernyataan skor total 4201 dengan rata-rata 4.62, dapat disimpulkan bahwa persepsi responden mengenai Kompetensi (X1) berada pada kategori sangat baik. Variabel Disiplin Kerja (X2), diwakili oleh 8 (delapan) item pernyataan skor total
2441 dengan rata-rata 4.36. dapat disimpulkan bahwa persepsi responden mengenai Disiplin Kerja (X2) berada pada kategori sangat baik. Variabel Komitmen Kerja (X3), diwakili oleh 6 (enam) item pernyataan skor total 1806 dengan rata-rata 4,30. dapat disimpulkan bahwa persepsi responden mengenai Komitmen Kerja (X3) berada pada kategori sangat baik. Variabel Kinerja Guru (Y), diwakili oleh 9 (sembilan) item pernyataan skor total 2651 dengan rata-rata 4,21. dapat disimpulkan bahwa persepsi responden mengenai Kinerja Guru (Y) berada pada kategori sangat baik.

\section{Hasil Persamaan Linear Berganda}

Diperoleh bentuk persamaan regresi linier berganda sebagai berikut :

$Y=-0.850+0.696 X_{1}+0.491 X_{2}+0.255 X_{3}$

Dari persamaan regresi linier berganda diatas diperoleh nilai konstanta koefisien kinerja guru sebesar -0.850 memiliki arti ketika kinerja guru tidak dipengaruhi oleh ketiga variabel bebasnya maka akan bernilai -0.850 . Tanda koefisien regresi variabel bebas menunjukkan arah hubungan dari variabel yang bersangkutan dengan Kinerja Guru. Koefisien regresi untuk variabel bebas $\mathrm{X}_{1}, \mathrm{X}_{2}$, 
$\mathrm{X}_{3}$ bernilai positif, menunjukkan adanya hubungan yang searah antara variabel bebas terhadap variabel terikat. Koefisien regresi variabel $X_{1}$ sebesar 0.696 mengandung arti untuk setiap peningkatan Kompetensi $\left(\mathrm{X}_{1}\right)$ sebesar satu satuan akan menyebabkan meningkatnya Kinerja Guru (Y) sebesar 0.696 satuan. Koefisien regresi variabel $\mathrm{X}_{2}$ sebesar 0.491 mengandung arti untuk setiap peningkatan Disiplin Kerja $\left(\mathrm{X}_{2}\right)$ sebesar satu satuan akan menyebabkan meningkatnya Kinerja Guru (Y) sebesar 0.491 satuan. Koefisien regresi variabel $\mathrm{X}_{3}$ sebesar 0.255 mengandung arti untuk setiap peningkatan Komitmen Kerja $\left(\mathrm{X}_{3}\right)$ sebesar satu satuan akan menyebabkan meningkatnya Kinerja Guru (Y) sebesar 0.255 satuan.

\section{Uji t}

Tabel 2 : Hasil Uji t

\begin{tabular}{|c|c|c|c|c|c|c|c|}
\hline \multicolumn{8}{|c|}{ Coefficients $^{a}$} \\
\hline \multirow{2}{*}{\multicolumn{2}{|c|}{ Model }} & \multicolumn{2}{|c|}{ Unstandardized Coefficients } & \multirow{2}{*}{$\begin{array}{c}\text { Standardized } \\
\text { Coefficients } \\
\text { Beta }\end{array}$} & \multirow[b]{2}{*}{$\mathrm{t}$} & \multirow[b]{2}{*}{ Sig. } & \multirow{2}{*}{$\begin{array}{l}\text { Correlations } \\
\text { Zero-order }\end{array}$} \\
\hline & & $\mathrm{B}$ & Std. Error & & & & \\
\hline \multirow[t]{3}{*}{1} & (Constant) & -.850 & .145 & & -5.884 & .000 & \\
\hline & Disiplin Kerja & .491 & .057 & .527 & 8.581 & .000 & .577 \\
\hline & Komitmen Kerja & .255 & .056 & .279 & 4.558 & .000 & .449 \\
\hline
\end{tabular}

Sumber: Hasil Pengolahan Data Primer, 2021

Berdasarkan tabel 2 di atas dapat dilihat bahwa Variabel Kompetensi $\left(\mathrm{X}_{1}\right)$ memiliki nilai sig lebih kecil dari 0,05. Karena nilai sig $(0,000)<0,05$, maka Ho ditolak. Oleh karena itu dapat disimpulkan bahwa secara parsial terdapat pengaruh signifikan dari Kompetensi terhadap Kinerja Guru. Variabel Disiplin Kerja $\left(\mathrm{X}_{2}\right)$ memiliki nilai sig lebih kecil dari 0,05. Karena nilai sig $(0,000)<0,05$, maka Ho ditolak. Oleh karena itu dapat disimpulkan bahwa secara parsial terdapat pengaruh signifikan dari Disiplin Kerja terhadap Kinerja Guru. Variabel Komitmen Kerja $\left(\mathrm{X}_{3}\right)$ memiliki nilai sig lebih kecil dari 0,05. Karena nilai sig $(0,000)<0,05$, maka Ho ditolak. Oleh karena itu dapat disimpulkan bahwa secara parsial terdapat pengaruh signifikan dari Komitmen Kerja terhadap Kinerja Guru. 


\section{Uji F}

Tabel 3 : Uji Hipotesis Simultan

\begin{tabular}{|c|c|c|c|c|c|c|}
\hline \multicolumn{7}{|c|}{ ANOVA $^{a}$} \\
\hline \multicolumn{2}{|c|}{ Model } & $\begin{array}{l}\text { Sum of } \\
\text { Squares }\end{array}$ & df & Mean Square & $\mathrm{F}$ & Sig. \\
\hline \multirow[t]{3}{*}{1} & Regression & 10.617 & 3 & 3.539 & 80.939 & $.000^{\mathrm{b}}$ \\
\hline & Residual & 2.886 & 66 & .044 & & \\
\hline & Total & 13.502 & 69 & & & \\
\hline \multicolumn{7}{|c|}{ a. Dependent Variable: Kinerja Guru } \\
\hline \multicolumn{7}{|c|}{ b. Predictors: (Constant), Komitmen Kerja, Kompetensi, Disiplin Kerja } \\
\hline
\end{tabular}

Sumber: Hasil Pengolahan Data Primer, 2021

Dari tabel 3, diperoleh nilai F hitung sebesar 80,939. Karena nilai $\mathrm{F}$ hitung $(80,939)>\mathrm{F}$ tabel $(2,74)$, maka Ho ditolak. Dengan demikian dapat disimpulkan bahwa secara simultan terdapat pengaruh yang signifikan dari Kompetensi, Disiplin Kerja, dan Komitmen Kerja terhadap Kinerja Guru..

\section{Koefisien Determinasi}

Tabel 4 : Koefisien Determinasi

\begin{tabular}{|c|c|c|c|c|}
\hline \multicolumn{5}{|c|}{ Model Summary } \\
\hline Model & $\mathrm{R}$ & R Square & $\begin{array}{l}\text { Adjusted R } \\
\text { Square }\end{array}$ & $\begin{array}{l}\text { Std. Error of } \\
\text { the Estimate }\end{array}$ \\
\hline 1 & $.887^{a}$ & .786 & .777 & .20910 \\
\hline
\end{tabular}

a. Predictors: (Constant), Komitmen Kerja, Kompetensi, Disiplin Kerja

b. Dependent Variable: Kinerja Guru

Sumber: Hasil Pengolahan Data Primer, 2021

Tabel di atas dapat diketahui bahwa nilai koefisien korelasi simultan adalah sebesar 0.887 kemudian koefisien determinasi $\left(\mathrm{R}^{2}\right)$ diperoleh nilai sebesar 0.786. Artinya total pengaruh antara variabel Kompetensi $\left(\mathrm{X}_{1}\right)$, Disiplin Kerja $\left(\mathrm{X}_{2}\right)$ dan Komitmen Kerja $\left(\mathrm{X}_{3}\right)$ terhadap Kinerja Guru sebesar 78.6\% sedangkan sisanya $21.4 \%$ merupkan pengaruh variabel-variabel lain yang tidak peneliti libatkan dalam penelitian ini.

\section{Pembahasan}

Pengaruh Kompetensi terhadap Kinerja Guru

Hasil yang didapatkan diperoleh dari perhitungan sig 0,000 lebih kecil dari 0,05 dan nilai thitung lebih besar dari tabel (10.959> 1.997). Pengaruh kompetensi secara partial besarnya adalah $35,7 \%$ terhadap kinerja guru, terbesar dibandingkan pengaruh dua variabel bebas lainnya. 
Hal ini sesuai dengan penelitian sebelumnya yang dilakukan oleh [26], [21], [25], dan [27] bahwa kompetensi berpengaruh secara signifikan dan positif terhadap kinerja.

\section{Pengaruh Disiplin Kerja terhadap Kinerja}

\section{Guru}

Hasil yang didapatkan diperoleh dari perhitungan sig 0,000 lebih kecil dari 0,05 dan nilai $t_{\text {hitung }}$ lebih besar dari $t_{\text {tabel }}(8,581>$ 1.997). Disiplin kerja memberikan kontribusi pengaruh secara partial terhadap kinerja guru sebesar $30,4 \%$

Hal ini sesuai dengan penelitian sebelumnya yang dilakukan oleh [28], [16], [17], dan [29] bahwa disiplin kerja berpengaruh secara signifikan dan positif terhadap kinerja.

\section{Pengaruh Komitmen Kerja terhadap Kinerja Guru}

Hasil yang didapatkan diperoleh dari perhitungan sig 0,000 lebih kecil dari 0,05 dan nilai $t_{\text {hitung }}$ lebih besar dari $t_{\text {tabel }}(4,558>$ 1.997). Komitmen kerja memberikan kontribusi pengaruh secara partial terhadap kinerja guru sebesar 12,5\% merupakan kontribusi terkecil dibandingkan dengan dua variabel bebas lainnya.

Hal ini sesuai dengan penelitian sebelumnya yang dilakukan oleh [30], [23], dan [31] bahwa komitmen kerja berpengaruh secara signifikan dan positif terhadap kinerja.

\section{KESIMPULAN}

1. a. Kompetensi guru SMA / SMK dengan nilai 4,62 dipersepsikan masuk kategori sangat baik, nilai tertinggi 4,84 dengan kategori sangat baik ada pada kemampuan guru dalam mengevaluasi belajar peserta didik, sementara nilai terendah 4,10 kategori baik yaitu kemampuan guru dalam mempergunakan teknologi informatika. b. Disiplin kerja guru SMA / SMK dengan nilai 4,36 dipersepsikan masuk kategori sangat baik, nilai tertinggi 4,73 (sangat baik) yaitu para guru taat dalam menjalankan ibadah, sementara nilai terendah 4,19 (baik) guru kurang disiplin dalam menjalankan perintah atasan.

c. Komitmen kerja guru SMA / SMK dengan nilai 4,30 dipersepsikan masuk dalam kategori sangat baik dimana nilai tertinggi sebesar 4,49 (SB) para guru merasa bahwa profesi guru adalah merupakan penghargaan sosial. Nilai terendah 4,17 (baik) para guru mengharapkan adanya penghargaan dari organisasi profesi guru.

d. Kinerja guru SMA / SMK dengan nilai 4,21 dipersepsikan sangat baik dimana nilai tertinggi 4,44 (sangat baik) para guru mampu mengendalikan suasana belajar yang kondusif, Nilai terendah 4,10 yaitu para guru belum memiliki inisiatif untuk penggunaan model pembelajaran yang variatif dan para guru belum mampu menguasai ketepatan materi ajar dengan karakteristik peserta didik.

2. Kompetensi memiliki nilai sig lebih kecil dari nilai 0,05 , maka Ho ditolak. 
Oleh karena itu dapat disimpulkan bahwa secara parsial terdapat pengaruh signifikan dari Kompetensi terhadap Kinerja Guru.

3. Disiplin kerja memiliki nilai sig lebih kecil dari nilai 0,05, maka Ho ditolak. Oleh karena itu dapat disimpulkan bahwa secara parsial terdapat pengaruh signifikan dari Disiplin Kerja terhadap Kinerja Guru.

4. Komitmen kerja memiliki nilai sig lebih kecil dari nilai 0,05, maka Ho ditolak. Oleh karena itu dapat disimpulkan bahwa secara parsial terdapat pengaruh signifikan dari Komitmen Kerja terhadap Kinerja.

5. Kompetensi, Disiplin kerja, dan Komitmen kerja memiliki nilai $\mathrm{F}$ hitung lebih besar dari nilai $\mathrm{F}$ tabel, maka Ho ditolak. Oleh karena itu dapat disimpulkan bahwa secara simultan terdapat pengaruh signifikan dari Kompetensi, Disiplin kerja, dan Komitmen kerja terhadap Kinerja guru.

\section{DAFTAR PUSTKA}

[1] F. O. Olaleye, "Improving Teacher Performance Competency Through Effective Human Resource Practices in Ekiti State Secondary Schools," Singaporean J. Bus. , Econ. Manag. Stud., vol. 1, no. 11, pp. 125-132, 2013, doi: 10.12816/0003819.

[2] S. Shukla, "Teaching Competency, Professional Commitment and Job Satisfaction-A Study of Primary School Teachers," IOSR J. Res. Method Educ., vol. 4, no. 3, pp. 44-64, 2014, doi: 10.9790/7388-04324464.

[3] L. I. Ahmad, "Konsep Penilaian
Kinerja Guru Dan Faktor Yang Mempengaruhinya," Idaarah J. Manaj. Pendidik., vol. 1, no. 1, pp. 133-142, 2017, doi: 10.24252/idaarah.v1i1.4133.

[4] BPS Kabupaten Garut, "Kabupaten Garut Dalam Angka 2020," Kabupaten Garut dalam Angka 2020, p. 221, 2020, [Online]. Available: https://garutkab.bps.go.id/publication/ download.html?nrbvfeve $=$ NzBkZjQ0 Njk1NTk2OWY1ZDMxZjJlMmMy\& xzmn=aHR0cHM6Ly9nYXJ1dGthYi 5icHMuZ28uaWQvcHVibGljYXRpb 24vMjAyMC8wNC8yNy83MGRmN DQ2OTU1OTY5ZjVkMzFmMmUy YzIva2FidXBhdGVuLWdhenV0LW RhbGFtLWFuZ2thLTIwMjAuaHRtb A\%253D.

[5] M. S. Panggabean and K. K. Himawan, "The Development of Indonesian Teacher Competence Questionnaire," J. Educ. Heal. Community Psychol., vol. 5, no. 2, p. 1, 2016, doi: 10.12928/jehcp.v5i2.5134.

[6] A. Siri, I. W. G. Supartha, I. P. G. Sukaatmadja, and A. G. Rahyuda, "Does teacher competence and commitment improve teacher's professionalism," Cogent Bus. Manag., vol. 7, no. 1, 2020, doi: 10.1080/23311975.2020.1781993.

[7] K. Selvi, "Teachers' competencies," Cult. Int. J. Philos. Cult. Axiolog., vol. 7, no. 1, pp. 167-175, 2010, doi: 10.5840/cultura20107133.

[8] E. Setyowati, "The Application on Teacher Discipline to Improve Teacher Performance; a Review," Iconect, 2019, doi: 10.4108/eai.20-82019.2288101.

[9] M. Rahimi and F. H. Karkami, "The role of teachers' classroom discipline in their teaching effectiveness and students' language learning motivation and achievement: A path method," Iran. J. Lang. Teach. Res., vol. 3, no. 1, pp. 57-82, 2015.

[10] A. Sudirman, D. Lie, S. Sherly, and E. Dharma, "The Impact of Work 
Discipline and Work Ethic on the Teacher Performance of Sultan Agung Pematangsiantar Private Middle School Teachers T.A. 2018/2019," Int. J. Bus. Stud., vol. 3, no. 3, pp. 125135, 2020, doi: 10.32924/ijbs.v3i3.83.

[11] Burmansah, B. Sujanto, and M. Mukhtar, "Work-life quality, job involvement, and affective commitment of school teachers," Int. J. Recent Technol. Eng., vol. 8, no. 2 Special Issue 9, pp. 159-164, 2019, doi: 10.35940/ijrte.B1034.0982S919.

[12] B. Utoyo, C. Yohana, and Mardi, "the Effect of Competence and Organizational Culture, on Performance of Employees With Work Motivation As a Mediation Variable," ResearchGate, no. May, pp. 1-19, 2019.

[13] K. Anwar and Muhammad Havidz Aima, "the Effect of Competence and Motivation on Organizational Commitments and Its Implications on Employee Performance," Dinasti Int. J. Educ. Manag. Soc. Sci., vol. 1, no. 2, pp. 183-196, 2020, doi: 10.31933/dijemss.v1i2.74.

[14] K. Koswara and R. Rasto, "Kompetensi Dan Kinerja Guru Berdasarkan Sertifikasi Profesi," $J$. Pendidik. Manaj. Perkantoran, vol. 1, no. 1, p. 61, 2016, doi: 10.17509/jpm.v1i1.3269.

[15] Y. L. Siregar, "Pengaruh kompetensi, motivasi, disiplin kerja dan komitmen organisasi terhadap kinerja pegawai pada kantor pelayanan pajak pratama tapak tuan.," J. Magister Manaj., vol. 2, no. 1, pp. 85-92, 2020.

[16] Suparno and Sudarwati, "Pengaruh Motivasi, Disiplin Kerja, dan Kompetensi Terhadap Kinerja Pegawai Dinas Pendidikan Kabupaten Sragen," J. Paradig., vol. 12, no. 1, 2014.

[17] F. R. Noel, J. Lapian, and M. Pandowo, "the Affect of Work Discipline and Competence on Employee Performance (Case Study At Balai Kesehatan Mata Masyarakat
Sulawesi Utara)," J. EMBA J. Ris. Ekon. Manajemen, Bisnis dan Akunt., vol. 5, no. 3, pp. 3528-3537, 2017, doi: 10.35794/emba.v5i3.17613.

[18] N. Syafrina, "Pengaruh Disiplin Kerja Terhadap Kinerja Karyawan Pada PT. Suka Fajar Pekan Baru," Eko dan Bisnis, vol. 4, no. 8, pp. 1-12, 2017, [Online]. Available: https://ekobis.stieriau-

akbar.ac.id/index.php/Ekobis/article/v iew/5.

[19] J. N. Liyas and R. Primadi, "Pengaruh disiplin kerja terhadap kinerja karyawan pada bank perkreditan rakyat," Al Masraf J. Lemb. Keuang. dan Perbank., vol. 2, no. 1, pp. 1-10, 2017.

[20] D. Sukmawati, "Pengaruh Motivasi, Disiplin, dan Kompetensi terhadap Kinerja Pegawa," J. Publik, no. 1, p. 183, 2018.

[21] I. A. O. Martini, A. A. N. E. Supriyadinata, K. E. Sutrisni, and I. W. G. Sarmawa, "The dimensions of competency on worker performance mediated by work commitment," Cogent Bus. Manag., vol. 7, no. 1, 2020 , doi: 10.1080/23311975.2020.1794677.

[22] P. Ayu Yuliantini, I. B. Putra Astika, and D. N. Badera, "Pengaruh Kompetensi Sumber Daya Manusia, Motivasi dan Lingkungan Kerja pada Komitmen Organisasi dan Implikasinya pada Kinerja Pengurus Barang Pemerintah Kabupaten Tabanan," E-Jurnal Ekon. dan Bisnis Univ. Udayana, vol. 10, p. 3697, 2017, doi: 10.24843/eeb.2017.v06.i10.p10.

[23] N. T. Nainggolan, R. Siahaan, and L. E. Nainggolan, "Dampak Komitmen Guru Terhadap Kinerja Guru Pada Smp Negeri 1 Panei," Mak. J. Manaj., vol. 6 , no. 1, pp. 1-12, 2020, doi: 10.37403/mjm.v6i1.144.

[24] Y. P. Sukamto, "Kompetensi guru, komitmen kerja, motivasi kerja, kinerja guru," J. Penelit. Ilmu Pendidik., vol. 9, no. 2, pp. 165-178, 2016. 
[25] B. Asmoro, N. Hamid, and W. Rasyid, "The Effect Work Culture and Competence on Commitment and Employee Performance of PT. Nindya Karya (Persero)," Hasanuddin J. Bus. Strateg., vol. 2, no. 1, pp. 34-48, 2020, doi: 10.26487/hjbs.v2i1.305.

[26] F. Adam and J. Kamase, "The effect competence and motivation to satisfaction and performance," Int. $J$. Sci. Technol. Res., vol. 8, no. 3, pp. 132-140, 2019.

[27] P. Halim, . N., S. Badruddin, A. Hidayat, and T. Maulamin, "Competence and Commitment: Two Factors that Impact Performance in Organizations," Helix, vol. 9, no. 4, pp. 5096-5101, 2019, doi: 10.29042/2019-5096-5101.

[28] Raniasari Bimanti Esthi \& Inggritz Savhira, "The Influence of Work Training, Competence and Discipline of Work on Employee Performance In PT. Lestarindo Perkasa," J. Reseacrh
Business, Econ. Educ., vol. 1, no. 2, p. 133, 2019.

[29] Kartawan, K. Ade, and R. Ros, "Pengaruh disiplin kerja, komitmen organisasi dan kompensasi terhadap kinerja pegawai rumah sakit umum daerah," J. Ekon. Manaj., vol. 2, no. 2, pp. 91-104, 2016.

[30] A. Lotunani, M. S. Idrus, E. Afnan, and M. Setiawan, "The Effect of Competence on Commitment , Performance and Satisfaction with Reward as a Moderating Variable ( A Study on Designing Work plans in Kendari City Government, Southeast Sulawesi )," Int. J. Bus. Manag. Invent., vol. 3, no. 2, pp. 18-25, 2014.

[31] Y. Sukamto and P. Pardjono, "Pengaruh Kompetensi Guru, Komitmen Kerja Dan Motivasi Kerja Terhadap Kinerja Guru Smp Andalan Di Sleman," J. Penelit. Ilmu Pendidik., vol. 9, no. 2, p. 165, 2017, doi: 10.21831/jpipfip.v9i2.12917. 